\title{
Assessment of materials and resources credit achievements of LEED- certified buildings in Turkey based on certification levels
}

\author{
Harun Turkoglu iD, Gul Polat*iD, Atilla Damci iD \\ Istanbul Technical University, Department of Civil Engineering, Istanbul, Turkey
}

\begin{abstract}
The construction industry is responsible for the consumption of large proportions of natural resources such as material, energy and water. Inefficient use of resources in the construction industry has a negative impact on the natural environment. In order to reduce these negative impacts on the natural environment, sustainable development has gained importance. "Green building" can be considered as the implementation of sustainable development principles in the construction industry. A building can be considered as "green" if it is evaluated and certified according to a recognized green building certification system such as LEED, BREAM, DGNB, BEPAC, CASBEE, etc. In Turkey, LEED is one of the most commonly preferred green building certification systems. In this green building certification system, "Materials and Resources" (MR) credit is one of the seven main credits and has 14 points, which accounts for approximately $13 \%$ of the maximum achievable points (110 pts. from seven different credits) for “New Construction” in LEED v3. However, the LEED certified green buildings in Turkey attain relatively low level of achievements in MR credit, regardless of the level of certification, especially when compared to the other categories. MR credit has seven sub-credits, which include: 1) building reuse, 2) construction waste management, 3) materials reuse, 4) recycled content, 5) regional materials 6) rapidly renewable materials, and 7) certified wood. The main objective of this study is to find out whether there are statistically significant differences between the MR credit achievements of 172 newly constructed and certified buildings in Turkey with respect to four different levels of certification. In addition, this study aims to investigate the potential reasons behind this low level of achievement in this credit. In this study, some recommendations have also been made to improve these low levels of achievements. These recommendations not only help the achievement of sustainability goals for construction projects, but also assist in attaining higher credit points during the application processes for green building certification.
\end{abstract}

\section{Keywords}

Green building; LEED; materials and resources; sustainability; Turkey

Received: 27 January 2020; Accepted: 26 February 2020

ISSN: 2630-5771 (online) (C) 2020 Golden Light Publishing All rights reserved.

\section{Introduction}

Nowadays, the number of new buildings and structures, especially housing projects, is increasing due to the growth of population. One of the main outputs of the construction industry is the buildings,

\footnotetext{
* Corresponding author

Email: polatgu@itu.edu.tr
}

and they have significant environmental, economic and social effects on the community during their lifecycle [1-3]. These effects may be either positive or negative. Construction activities have positive effects, such as providing buildings and facilities to meet the needs of human beings, providing new 
business areas and employment opportunities, and contributing to national economy [2]. Moreover, construction is a major industry around the world, which accounts for a large share of the Gross Domestic Product (GDP) of most countries [4]. For example, the construction industry in Turkey, which accounts for about $8-9 \%$ of the GDP and employs 2 million people, plays an important role in the country's economic development [5]. On the other hand, buildings and construction activities have also negative effects, such as noise, air pollution, the consumption of natural resources (material, energy, water etc.), water pollution, waste disposal, and carbon dioxide (CO2) emissions [2]. For example, in many developed countries, such as the United States, buildings are responsible for nearly $30 \%$ of greenhouse gas production, $20 \%$ of solid waste streams, and consuming approximately $70 \%$ of electricity, about $15 \%$ of drinking water and $40 \%$ of raw materials [ 4 , 6]. Obviously, the construction industry can be seen as a burden on the natural environment [7]. Therefore, the negative effects of activities in construction projects on the natural environment are frequently discussed and investigated. In order to eliminate, if possible, or minimize all these negative effects, the construction industry has begun to employ sustainable practices [8]. In addition, with the development of ecological awareness, the interest in sustainable construction has gained momentum especially in recent years [3, $4,8,9]$ and the number of studies related to this subject has increased significantly [10]. Sustainable development in the design and construction of buildings, which is a dynamic process, aims to improve and preserve "environmental health or associated health and well-being of building residents, construction workers, the general public or future generations" [11]. In other words, sustainable development in construction focus on understanding how the design and construction of buildings can better serve both human and environmental needs [12]. Green building can be considered as the implementation of sustainable development principles in the construction industry [13]. Therefore, it can be considered as a subset of sustainable construction and is a key step for achieving sustainable development in the construction industry [7]. Furthermore, nowadays, the concept of "green building" has become an obligation rather than an alternative [14].

There are several definitions for the term "green building" [7], as there is a continuous improvement in the definition of what a "green building" refers to [15]. Green buildings can be defined as structures that are designed and built to mitigate all of the negative effects of traditional (non-green) buildings on human health and the natural environment by using energy, water and other resources in a more efficient way, using recycled materials, improving the health conditions of occupants, increasing employee productivity and indoor air quality, and reducing waste, pollution and environmental degradation during their lifecycle $[3,7,13]$. Green building is an effective tool for implementing environmental, economic and social sustainability in the construction industry [6]. Green buildings are energy and resource efficient buildings throughout lifecycle [7]. Although there are many different definitions on the concept of green building, in light of the review of relevant literature, the following common points of these definitions have been observed: the lifecycle points of view, environmental sustainability, health problems, and effects on society [2]. Furthermore, green buildings have four basic pillars: (1) minimizing the negative effects of buildings on the natural environment, (2) increasing the health conditions of users, (3) return on investment for investor and the local society, and (4) taking into consideration the lifecycle of buildings [16]. In addition to the environmental benefits, the implementation of green buildings offers many social and economic benefits to the construction industry [6].

Green building certification systems are designed to examine and evaluate the life cycle impacts of buildings on the environment [17]. For this reason, various green building certification systems have been developed in different countries [18]. These systems can be considered as effective tools in the process of transforming the construction industry to green. If a building is certified according 
to any of these green building certification systems, then it can be considered as "green" [19]. While developed countries have established their own green building certification systems by considering their local standards, environmental conditions, geographical characteristics and living conditions, other countries have adapted these ones and even some countries directly apply these ones [8]. Some of the widely used and recognized green building certification systems are: Building Research Establishment Environmental Assessment Method (BREEAM), Leadership in Energy and Environmental Design (LEED), Green Star, Deutsche Gesellschaft für Nachhaltiges Bauen e.V. (DGNB), Building Environmental Performance Assessment Criteria (BEPAC) and Comprehensive Assessment System for Built Environment Efficiency (CASBEE) [20, 21].

The number of green buildings and the demand for them have increased considerably in recent years in developing countries such as Turkey. Although LEED is designed in accordance with the conditions, practices, and laws and regulations of the U.S. construction industry, LEED has become an extensively used green building certification system in the construction industry, not only within the United States, but also all over the world. LEED, which has been updated and introduced in new versions since its first use, is the world's most widely used green building certification system with 122,669 registered and certified projects in more than 167 countries and regions as of February 2020 [22]. Moreover, LEED is one of the most widely preferred green building certification systems in Turkey [10]. U.S. Green Building Council (USGBC), the creators of the LEED green building certification system, announced the annual Top 10 Countries and Regions for LEED, which is a list that highlights countries outside the United States where LEED originated. According to this list, Mainland China ranked first on the list as the largest market of LEED, with more than 68 million Gross Square Meters (GSM) of certified LEED space. Turkey, with 337 certified buildings and 10.90 million GSM of LEED certified space, ranked 6th in the Top 10 Countries and Regions for LEED [23].

LEED includes different rating systems according to types and phases of buildings: Building Design and Construction (BD+C), Interior Design and Construction (ID+C), Building Operations and Management $(\mathrm{O}+\mathrm{M})$, Neighborhood Development (ND), and Homes [24]. The system prepared for buildings that are newly constructed or going through a major renovation is $\mathrm{BD}+\mathrm{C}$.

Table 1. Top 10 countries and regions list for LEED.

\begin{tabular}{cccc}
\hline Ranking & Country/Region & Number of Projects & Gross Square Meters (millions) \\
\hline 1 & Mainland China & 1,494 & 68.83 \\
2 & Canada & 3,254 & 46.81 \\
3 & India & 899 & 24.81 \\
4 & Brazil & 531 & 16.74 \\
5 & Republic of Korea & 143 & 12.15 \\
6 & Turkey & 337 & 10.90 \\
7 & Germany & 327 & 8.47 \\
8 & Mexico & 370 & 8.41 \\
9 & China, Taiwan & 144 & 7.30 \\
10 & Spain & 299 & 5.81 \\
$*$ & United States & 33,632 & 441.60 \\
\hline
\end{tabular}

* The United States is not included on the list, but remains the world's largest market for LEED. 
The types of building projects for which BD + C can be applied are as follows: new construction and major renovation (NC), core and shell development, schools, retail, healthcare, data centers, hospitality, and warehouses and distribution centers [25]. Each rating system is categorized into five basic environmental categories: (1) Sustainable sites, (2) Water efficiency, (3) Energy and atmosphere, (4) Materials and resources, and (5) Indoor environmental quality [26]. Buildings must fulfill certain prerequisites and also earn some points from these categories in order to obtain a LEED certification at any level. With the widespread use of LEED in countries outside the United States, local, geographical and legal differences have become increasingly important in terms of earning points. For this reason, some special credits have been added to the system, while others have allowed users to develop alternatives. Since it was first introduced, many versions of LEED have been issued, but most of the credits to earn points and their prerequisites required to fulfill have remained the same. LEED v3 was published in April 2009. Although the LEED v4.1 is the latest version released in first quarter 2018, the use of LEED v3 was allowed until October 31, 2016 [8]. As a result, the number of buildings certified according to LEED v3 is considerably higher when it is compared to the ones certified according to LEED v4. Furthermore, the LEED certified green buildings commonly attain relatively low level of achievements in MR credit, regardless of the level of certification, especially when compared to the other categories [17]. Therefore, the examination of buildings that have been certified with the LEED v3 is important in terms of demonstrating the level of achievements of MR credit in green building projects. This analysis is meaningful and important in terms of understanding the difficulties and risks encountered within the scope of MR credit in green building projects.

The main purpose of this study is to investigate whether there were statistically significant differences between the MR credit achievements of newly constructed buildings in Turkey, which were certified according to four different levels. In addition, this study aims to determine which of these MR sub-categories' credit achievements are weak. To achieve these objectives, Kruskal-Wallis and Mann-Whitney $U$ tests were performed respectively and the findings were interpreted.

\section{LEED certification system for new construction}

LEED BD + C provides a framework for construction a holistic green building, which uses water and energy efficiently, damages the environment less and provides more healthy livable spaces. The system can be applied for eight different types of projects, which are: (1) new construction, (2) core and shell, (3) schools, (4) retail, (5) hospitality, (6) data centers, (7) warehouses and distribution centers, and (8) healthcare. The system also includes design and construction activities for both new buildings and major renovations of existing buildings [25]. Until a project obtains the certificate, a maximum of $40 \%$ of its gross floor area may not be completed, otherwise it will not obtain the certificate until the deficiencies have been completed [8].

In LEED, which is a point-based certification system, a project fulfills specific prerequisites and credits to earn LEED points. The range of credits' possible points and total points vary depending on the rating system where the building type is eligible to apply. In LEED v3, which has the highest score of 110 , a project must earn 40 or more credit points in order to obtain a certificate. In LEED, buildings acquire four different levels of certification: Certified (40-49 points), Silver (50-59 points), Gold (60-79 points) and Platinum (80 and over points) [15]. These levels are determined by sum of the points earned from each credit of the projects. The sustainability of buildings is evaluated in seven credits for New Construction with LEED v3 2009. MR credit is one of the seven main credits and accounts for approximately $13 \%$ of the maximum achievable points (110 pts.) for NC in LEED v3. In MR credit, there are 8 different evaluation criteria including 1 prerequisite and 7 credits [25]. Prerequisite and points of MR credit are presented in Table 2. 
Table 2. Materials and resources credit in LEED v3 2009 for new construction

\begin{tabular}{|c|c|c|}
\hline \multicolumn{2}{|c|}{ Materials and Resources Credit and Its Prerequisites } & \multirow{2}{*}{$\begin{array}{c}\text { Points } \\
\text { Required }\end{array}$} \\
\hline Prerequisite 1 & Storage and Collection of Recyclables & \\
\hline Credit 1.1 (C1.1) & $\begin{array}{l}\text { Building Reuse-Maintain Existing Walls, Floors and Roof } \\
\text { The minimum percentage building reuse }\end{array}$ & 1-3 Points \\
\hline & $55 \%$ & 1 \\
\hline & $75 \%$ & 2 \\
\hline & $95 \%$ & 3 \\
\hline Credit 1.2 (C1.2) & Building Reuse-Maintain Interior Nonstructural Elements & 1 Point \\
\hline \multirow[t]{4}{*}{ Credit 2 (C2) } & Construction Waste Management & 1-2 Points \\
\hline & The minimum percentage debris to be recycled or salvaged & \\
\hline & $50 \%$ & 1 \\
\hline & $75 \%$ & 2 \\
\hline \multirow[t]{4}{*}{ Credit 3 (C3) } & Materials Reuse & 1-2 Points \\
\hline & The minimum percentage materials reused & \\
\hline & $5 \%$ & 1 \\
\hline & $10 \%$ & 2 \\
\hline \multirow[t]{4}{*}{ Credit 4 (C4) } & Recycled Content & 1-2 Points \\
\hline & The minimum percentage materials recycled & \\
\hline & $10 \%$ & 1 \\
\hline & $20 \%$ & 2 \\
\hline \multirow[t]{4}{*}{ Credit 5 (C5) } & Regional Materials & 1-2 Points \\
\hline & The minimum percentage regional materials & \\
\hline & $10 \%$ & 1 \\
\hline & $20 \%$ & 2 \\
\hline Credit 6 (C6) & Rapidly Renewable Materials & 1 Point \\
\hline \multirow[t]{2}{*}{ Credit 7 (C7) } & Certified Wood & 1 Point \\
\hline & The maximum achievable points & 14 Points \\
\hline
\end{tabular}

\section{Materials and resources credit achievements of LEED certified building in Turkey}

The life cycle of a material consists of five main phases: the extraction of material from its source, then processing, production, transportation, consumption, reuse, recovery and disposal of material [27]. Each phase of a material's life cycle has various adverse environmental effects and these effects damage nature. Therefore, all of these phases should be taken into consideration when deciding the construction materials to be used in the structures. Effective use of construction materials can be achieved through practices such as use of standardized material, selection of recyclable materials, and development of material management plan. According to LEED, the environment should not be harmed by using the necessary amount of, compatible with the region and recyclable materials in these processes. MR credit focuses on minimizing the negative environmental impacts associated with the extraction, processing, transportation, maintenance and disposal of construction materials [28]. MR credit supports the use of sustainable materials and 
recycling of waste as buildings cause large amounts of materials and resources consumption and waste generation in construction and operation processes [25]. It aims to minimize resource consumption and waste during the lifecycle of buildings.

There are 831 registered projects in Turkey according to the USGBC project official website data. Out of 831, 461 were classified as New Construction and 380 of them were assessed according to LEED v3. Out of these 380 projects, 172 projects obtained certificate after the assessment process. The scorecards of these 172 projects were obtained from the USBGC project official website data. Average values, standard deviations and percentage of MR credit achievements according to certification levels, and the number of projects for each certification level are given in Table 3.

The comparison of the percentages of MR credit achievements of 172 green buildings with respect to different certification levels is presented in Fig. 1.

Table 3. MR credit achievements of LEED-NC 2009 certified buildings in Turkey.

\begin{tabular}{|c|c|c|c|c|c|c|c|c|c|c|c|c|}
\hline \multirow{3}{*}{$\begin{array}{l}\text { Credits and } \\
\text { Max. } \\
\text { Achievable } \\
\text { Points }\end{array}$} & \multicolumn{12}{|c|}{ Certification Level and Number of Buildings } \\
\hline & \multicolumn{3}{|c|}{ Certified (10) } & \multicolumn{3}{|c|}{ Silver (36) } & \multicolumn{3}{|c|}{ Gold (111) } & \multicolumn{3}{|c|}{ Platinum (15) } \\
\hline & Ave. & $\begin{array}{l}\text { Std. } \\
\text { Dev. }\end{array}$ & $\begin{array}{c}\text { Ach. } \\
\%\end{array}$ & Ave. & $\begin{array}{l}\text { Std. } \\
\text { Dev. }\end{array}$ & $\begin{array}{c}\text { Ach. } \\
\%\end{array}$ & Ave. & $\begin{array}{l}\text { Std. } \\
\text { Dev. }\end{array}$ & $\begin{array}{c}\text { Ach. } \\
\%\end{array}$ & Ave. & $\begin{array}{l}\text { Std. } \\
\text { Dev. }\end{array}$ & $\begin{array}{c}\text { Ach. } \\
\%\end{array}$ \\
\hline C1.1 (3) & 0.00 & 0.00 & 0.00 & 0.25 & 0.71 & 8.33 & 0.15 & 0.37 & 5.11 & 0.13 & 0.27 & 4.44 \\
\hline C1.2 (1) & 0.00 & 0.00 & 0.00 & 0.03 & 0.03 & 2.78 & 0.02 & 0.02 & 1.80 & 0.00 & 0.00 & 0.00 \\
\hline C2 (2) & 1.60 & 0.71 & 80.00 & 1.11 & 0.67 & 55.56 & 1.54 & 0.56 & 77.03 & 1.67 & 0.52 & 83.33 \\
\hline C3 (2) & 0.00 & 0.00 & 0.00 & 0.03 & 0.03 & 1.39 & 0.05 & 0.07 & 2.70 & 0.27 & 0.50 & 13.33 \\
\hline C4 (2) & 1.80 & 0.40 & 90.00 & 1.69 & 0.39 & 84.72 & 1.83 & 0.20 & 91.44 & 1.87 & 0.27 & 93.33 \\
\hline C5 (2) & 1.00 & 1.11 & 50.00 & 1.69 & 0.50 & 84.72 & 1.95 & 0.08 & 97.75 & 2.00 & 0.00 & 100.00 \\
\hline C6 (1) & 0.00 & 0.00 & 0.00 & 0.03 & 0.03 & 2.78 & 0.11 & 0.10 & 10.81 & 0.20 & 0.17 & 20.00 \\
\hline C7 (1) & 0.00 & 0.00 & 0.00 & 0.00 & 0.00 & 0.00 & 0.05 & 0.04 & 4.50 & 0.07 & 0.07 & 6.67 \\
\hline
\end{tabular}

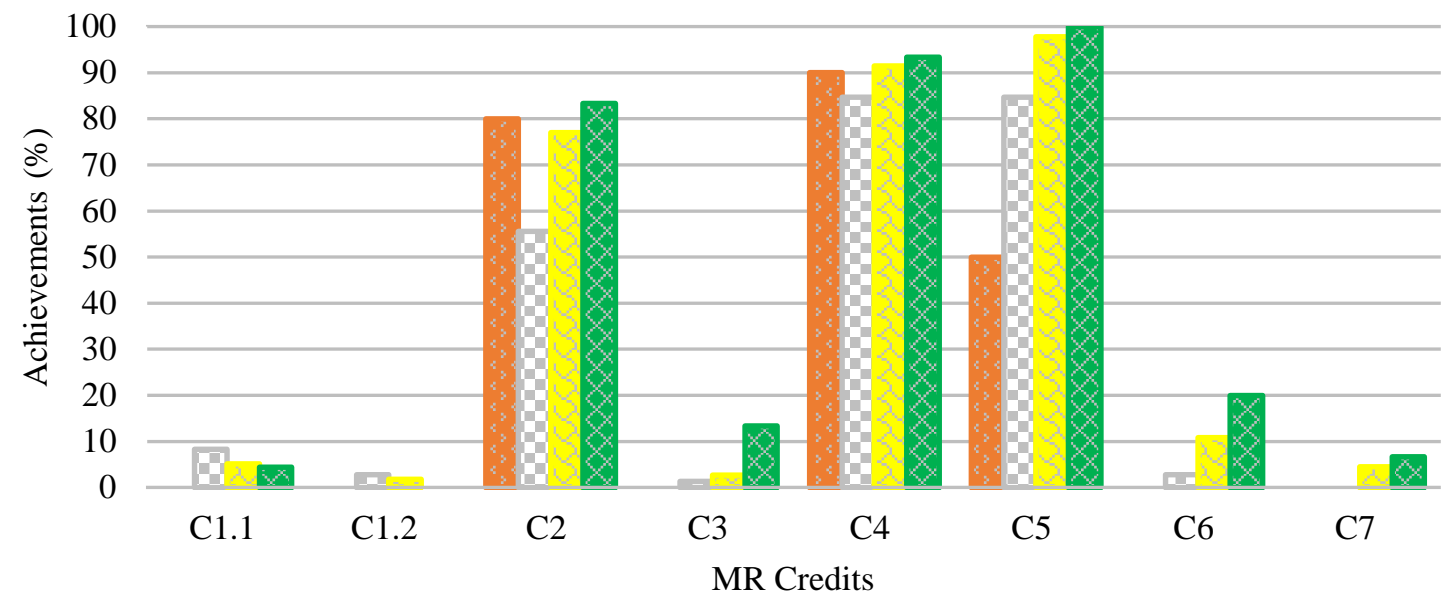

- Certified $\square$ Silver Gold Platinum

Fig. 1. Comparison of MR credit achievements of LEED-NC 2009 certified buildings 
According to Table 3 and Fig. 1, the following results can be interpreted:

- In building reuse-maintain existing walls, floors and roof (C1.1) credit, the percentages of achievements of gold and platinum buildings are very close. The percentages of achievements of certified buildings are equal to $0 \%$, in other words these buildings have not earned any points in this credit. The percentages of achievements of silver buildings are high when compared to the ones in other certification levels.

- In building reuse-maintain interior nonstructural elements (C1.2) credit, the percentages of achievements of certified and platinum buildings are equal to $0 \%$, in other words these buildings have not earned any points in this credit. The percentages of achievements of silver and gold buildings are slightly more than $0 \%$ and very close to each other.

- In construction waste management (C2) credit, the percentages of achievements of certified, gold and platinum buildings are very close. The percentages of achievements of silver buildings are very low when compared to the ones in other certification levels.

- In materials reuse (C3) credit, the percentages of achievements of certified buildings are equal to $0 \%$. The percentages of achievements of gold and silver buildings are slightly more than $0 \%$ and very close to each other. The percentages of achievements of platinum buildings are high when compared to the ones in other certification levels.

- In recycled content (C4) credit, the percentages of achievements of certified, gold and platinum buildings are very close. The percentages of achievements of silver buildings are low when compared to the ones in other certification levels.

- In regional materials (C5) credit, the percentages of achievements of platinum buildings are equal to $100 \%$, in other words all of them have earned possible maximum points in this credit. In addition, the percentages of achievements of gold and platinum buildings are very close. The percentages of achievements of silver buildings are lower than the ones in gold and platinum certification levels while they are higher than the ones in certified certification level. The percentages of achievements of certified buildings are very low when compared to the ones in other certification levels.

- In rapidly renewable materials (C6) credit, the percentages of achievements of certified buildings are equal to $0 \%$. The percentages of achievements of silver buildings are slightly more than $0 \%$ and very close to the ones in certified certification level. The percentages of achievements of platinum buildings are very high when compared to the ones in other certification levels.

- In certified wood (C7) credit, the percentages of achievements of certified and silver buildings are equal to $0 \%$. The percentages of achievements of gold and platinum buildings are slightly more than $4 \%$ and very close to each other.

- In summary, only in C2, C4 and C5 credits, the percentages of achievements of all buildings are higher than $50 \%$, whereas in other credits, they are lower than $50 \%$.

The main purpose of this study is to determine whether there were statistically significant differences between the MR credit achievements of newly constructed buildings in Turkey depending on four different levels of certification. For this purpose, Kruskal-Wallis test was performed by using the IBM ${ }^{\circledR}$ SPSS ${ }^{\circledR}$ Statistics version 25 software.

Kruskal-Wallis test is the non-parametric alternative to one-way variance analysis (ANOVA). Kruskal-Wallis test is used to determine whether there is a statistically significant difference between averages of three or more groups that do not show normal distribution [29]. Kruskal-Wallis test can be performed for continuous or ordinal dependent variables [30]. The $p$ values obtained from the Kruskal-Wallis test performed in this study are presented in Table 4 . If the $p$ values are less than 0.05 , it indicates that there is a statistically 
significant difference in MR credit achievements of buildings certified according to different certification levels at 95\% significance level.

Based on the results of Kruskal-Wallis test presented in Table 4, p values are less than 0.05 for 2 MR credits. This means that the achievements of buildings certified according to four certification levels are statistically significant different at 95\% significance level in the construction waste management (C2) and regional materials (C5) credits. On the other hand, the achievements of buildings certified according to four certification levels are not statistically significant different at 95\% significance level in the remaining $6 \mathrm{MR}$ credits.

Having performed the Kruskal-Wallis test, the Mann-Whitney $U$ test was performed in order to determine whether there is a statistically significant difference in credit achievements of buildings certified according to two different certification levels. Mann-Whitney $U$ test is the non-parametric alternative to the independent sample t-test. It is used to test whether the averages of two independent groups that do not show normal distribution are equal or not [29, 30]. The $p$ values obtained from the Mann-Whitney $U$ test used in this study are presented in Table 5 . If the $\mathrm{p}$ values are less than 0.05 , it indicates that there is a statistically significant difference in credit achievements of buildings certified according to two certification levels at 95\% significance level.

According to the Mann-Whitney U Test results presented in Table 5, following findings can be highlighted:
- In building reuse-maintain existing walls, floors and roof (C1.1), building reuse-maintain interior nonstructural elements (C1.2), materials reuse (C3), recycled content (C4), rapidly renewable materials (C6) and certified wood (C7) credits, the average achievements of all types of certificated buildings are at the same level, and therefore there is no statistically significant difference within each pair in these credits.

- In construction waste management (C2) credit, the average achievement of silver buildings is considerably lower than those of gold and platinum buildings, and so there is a statistically significant difference between them. Certified, gold and platinum buildings have almost at the same average level of achievement and so there is no statistically significant difference among them.

- In regional materials (C5) credit, the average achievement of certified buildings is considerably lower than those of silver, gold and platinum buildings, and therefore there is a statistically significant difference between them. Moreover, the average achievement of silver buildings is considerably lower than those of gold and platinum buildings, and therefore there is a statistically significant difference between silver buildings and gold ones. The average achievements of silver and platinum buildings, and gold and platinum buildings are respectively at the same level, and so there is no statistically significant difference within each pair.

Table 4. Kruskal-Wallis Test $p$ values of MR credit.

\begin{tabular}{cc}
\hline MR Credits & Kruskal-Wallis Test $p$ Value \\
\hline Building Reuse-Maintain Existing Walls, Floors and Roof & 0.810 \\
Building Reuse-Maintain Interior Nonstructural Elements & 0.881 \\
Construction Waste Management & $\mathbf{0 . 0 0 8 *}$ \\
Materials Reuse & 0.314 \\
Recycled Content & 0.495 \\
Regional Materials & $\mathbf{0 . 0 0 0 *}$ \\
Rapidly Renewable Materials & 0.161 \\
Certified Wood & 0.486 \\
\hline
\end{tabular}

* Statistically significant at 95\%. 
Table 5. Mann-Whitney U test $p$ values of MR credit

\begin{tabular}{|c|c|c|c|c|c|}
\hline \multirow{2}{*}{ MR Credit } & \multirow{2}{*}{ Certification Level } & \multicolumn{4}{|c|}{ Mann-Whitney U Test $p$ Values } \\
\hline & & Certified & Silver & Gold & Platinum \\
\hline \multirow{4}{*}{ C1.1 (3) } & Certified & - & 0.350 & 0.415 & 0.414 \\
\hline & Silver & & - & 0.631 & 0.790 \\
\hline & Gold & & & - & 0.979 \\
\hline & Platinum & & & & - \\
\hline \multirow{4}{*}{ C1.2 (1) } & Certified & - & 0.598 & 0.670 & 1.000 \\
\hline & Silver & & - & 0.720 & 0.519 \\
\hline & Gold & & & - & 0.602 \\
\hline & Platinum & & & & - \\
\hline \multirow{4}{*}{ C2 (2) } & Certified & - & 0.074 & 0.623 & 0.936 \\
\hline & Silver & & - & $0.002^{*}$ & $0.019 *$ \\
\hline & Gold & & & - & 0.452 \\
\hline & Platinum & & & & - \\
\hline \multirow{4}{*}{ C3 (2) } & Certified & - & 0.598 & 0.495 & 0.238 \\
\hline & Silver & & - & 0.646 & 0.135 \\
\hline & Gold & & & - & 0.141 \\
\hline & Platinum & & & & - \\
\hline \multirow{4}{*}{ C4 (2) } & Certified & - & 0.453 & 0.779 & 0.768 \\
\hline & Silver & & - & 0.239 & 0.218 \\
\hline & Gold & & & - & 0.461 \\
\hline & Platinum & & & & - \\
\hline \multirow{4}{*}{ C5 (2) } & Certified & - & $0.025 *$ & $0.000 *$ & $0.003^{*}$ \\
\hline & Silver & & - & $0.002^{*}$ & 0.096 \\
\hline & Gold & & & - & 0.521 \\
\hline & Platinum & & & & - \\
\hline \multirow{4}{*}{ C6 (1) } & Certified & - & 0.598 & 0.275 & 0.140 \\
\hline & Silver & & - & 0.142 & $0.039 *$ \\
\hline & Gold & & & - & 0.304 \\
\hline & Platinum & & & & - \\
\hline \multirow{4}{*}{ C7 (1) } & Certified & - & 1.000 & 0.495 & 0.414 \\
\hline & Silver & & - & 0.197 & 0.121 \\
\hline & Gold & & & - & 0.713 \\
\hline & Platinum & & & & - \\
\hline
\end{tabular}

* Statistically significant at 95\%. 
- In rapidly renewable materials (C6) credit, the average achievement of silver buildings is considerably lower than those of gold and platinum buildings, and thus there is a statistically significant difference between silver buildings and platinum ones. There is no considerable difference among the average achievements of buildings with the other certification levels, and thus there is a statistically significant difference among them.

\section{Findings and conclusion}

Buildings and construction activities have negative effects on the natural environment. The construction industry is responsible for consuming half of the world's physical resources. Therefore, the construction industry can be considered as an environmental burden. With the development of ecological consciousness, the interest in sustainable construction has gained momentum especially in recent years. The "green building" has emerged as a response to the sustainable development of the construction industry and become an obligation rather than an alternative. If a building has been certified by any green building certification system, then it can be considered as "green". There are various green building certification systems such as LEED, BREAM, DGNB, BEPAC, CASBEE, etc. developed in different countries around the world. LEED is one of the most widely preferred green building certification system in Turkey. In this certification system, buildings can receive at most 110 credit points from seven different credits and "Materials and Resources” (MR) credit has 14 credit points, which accounts for approximately $13 \%$ of the maximum credit points in LEED v3 for "New Construction". Although MR credit is important for obtaining any LEED certification, the LEED certified green buildings in Turkey attain relatively low level of achievements in this credit, regardless of the levels of certification, especially when compared to the other credits. The number of buildings certified according to LEED v3 is considerably higher when compared to the ones certified according to LEED v4. Therefore, the examination of buildings that have been certified with the LEED v3 is important in terms of demonstrating the level of achievements of MR credit in green building projects. The main purpose of this study is to investigate whether there were statistically significant differences between the MR credit achievements of newly constructed buildings in Turkey, which were certified according to four different levels. In addition, this study aims to determine which of these MR credit achievements are weak. For these purposes, Kruskal-Wallis and Mann-Whitney U tests were performed respectively and then the findings were interpreted.

The analyses revealed that the achievements in the building reuse-maintain existing walls, floors and roof (C1.1), building reuse-maintain interior nonstructural elements (C1.2), materials reuse (C3), rapidly renewable materials (C6) and certified wood (C7) credits of green buildings are relatively low when compared to the ones in other credits. Moreover, the maximum average achievement of all LEED certified buildings in C3 and C6 credits is $20 \%$ and even $10 \%$ in C1.1, C1.2 and C7 credits. There may be several reasons behind these low levels of achievements. First of all, the term "green building" in developing countries such as Turkey has gained importance recently, that is not a very mature culture. Secondly, it is generally difficult to meet the requirements of MR credit. For example, in the "certified wood (C7)" credit, whether the FSC certificate exists is evaluated. In order to obtain this certificate, the authorized institution must be present in the countries in which the project is applied. For this reason, this certificate is not very common, so very few projects have received less credit points from "certified wood (C7)" credit and even the majority of the projects have not received any credit points from this credit. In the other example, the projects have either received little or no credit points from the "materials reuse (C3)" and "rapidly renewable materials (C6)" credits. Because, the evaluation of these credits is based on the ratio of amount of rapidly renewable materials and reusable materials to the quantity of all materials, respectively. Since threshold ratio is very high, most of the projects attain low level of achievements regardless of the levels of 
Turkoglu et al.

certification. The requirements of the "construction waste management (C2)", recycled content (C4) and "regional materials (C5)" credits have been met with high credit points in most projects, regardless of the levels of certification. This may indicate that recycling and use of local materials in green buildings has been important recently. Thirdly, as the recycled and eco-friendly materials industry in Turkey is relatively new concept, it is very difficult to supply local materials that meet certification requirements. Fourthly, renewable energy sources such as solar, wind, geothermal etc. is very limited. Fifthly, the production of reusable, recyclable and renewable materials is very limited, so most of them are imported, which in turn increases the purchasing cost and causes problems in supply.

This study demonstrated the MR credit achievements of newly constructed buildings in Turkey, which were certified according to four different levels. This study also explored the possible causes of low levels of achievements in certain credits (C1.1, C1.2, C3, C6, C7) of these projects. In this study, the factors that cause low level of achievements in the MR credit are examined and presented to the attention of professionals working in the construction industry. In order to improve these low levels of achievements, green technologies such as solar energy, day-lighting should be used instead of electricity, and practices such as minimizing waste, water conservation and using sustainable materials during the construction of projects should be adopted. Moreover, sustainable and resource efficient design, off-site preparation, appropriate and reuse of resources, the development of production and supply chain of local materials, and the application of modern construction methods will make the construction industry more economical and green. These recommendations not only help the achievement of sustainability goals for construction projects, but also contribute to obtaining higher credit points during the application processes for green building certification. Future studies may aim to better understand sustainable construction practices by examining the performance of the other categories of LEED in Turkey.

\section{Declaration of conflicting interests}

The author(s) declared no potential conflicts of interest with respect to the research, authorship, and/or publication of this article.

\section{References}

[1] Gou Z, Lau SSY (2014). Contextualizing green building rating systems: Case study of Hong Kong. Habitat International 44:282-289.

[2] Zuo J, Zhao ZY (2014). Green building researchcurrent status and future agenda: A review. Renewable and Sustainable Energy Reviews 30:271-281.

[3] Darko A., Zhang C, Chan AP (2017). Drivers for green building: A review of empirical studies. Habitat International 60:34-49.

[4] Chan EH, Qian QK, Lam PT (2009). The market for green building in developed Asian cities-the perspectives of building designers. Energy Policy 37(8):3061-3070.

[5] Turkish Contractors Association (TCA) (2018). Brief Review Report of the Turkish Overseas Contracting Services, TCA, Turkey.

[6] Darko A, Chan APC, Ameyaw EE, He BJ, Olanipekun AO (2017). Examining issues influencing green building technologies adoption: The United States green building experts' perspectives. Energy and Buildings 144:320-332.

[7] Hwang BG, Tan JS (2012). Green building project management: obstacles and solutions for sustainable development. Sustainable Development 20(5):335-349.

[8] Gurgun AP, Polat G, Damci A, Bayhan HG (2016). Performance of LEED energy credit requirements in European countries. Procedia Engineering 164:432-438.

[9] Karakhan AA, Gambatese JA (2017). Identification, quantification, and classification of potential safety risk for sustainable construction in the United States. Journal of Construction Engineering and Management 143(7):04017018.

[10] Aktas B, Ozorhon B (2015). Green building certification process of existing buildings in developing countries: Cases from Turkey. Journal of Management in Engineering 31(6):05015002. 
[11] Marjaba GE, Chidiac SE (2016). Sustainability and resiliency metrics for buildings-Critical review. Building and Environment 101:116-125.

[12] Raslanas S, Zavadskas EK, Kaklauskas A (2010). Land value tax in the context of sustainable urban development and assessment. Part i-policy analysis and conceptual model for the taxation system on real property. International Journal of Strategic Property Management 14(1):73-86.

[13] Olubunmi OA, Xia PB, Skitmore M (2016). Green building incentives: A review. Renewable and Sustainable Energy Reviews 59:1611-1621.

[14] Chan S (2014). Comprehension of green buildings for general population in Taiwan. Bulletin of Japanese Society for the Science of Design 60(5):31-38.

[15] Uğur LO, Leblebici N (2018). An examination of the LEED green building certification system in terms of construction costs. Renewable and Sustainable Energy Reviews 81:1476-1483.

[16] Mattoni B, Guattari C, Evangelisti L, Bisegna F, Gori P, Asdrubali F (2018). Critical review and methodological approach to evaluate the differences among international green building rating tools. Renewable and Sustainable Energy Reviews 82:950-960.

[17] Wu P, Song Y, Shou W, Chi H, Chong HY, Sutrisna M (2017). A comprehensive analysis of the credits obtained by LEED 2009 certified green buildings. Renewable and Sustainable Energy Reviews 68:370-379.

[18] Ding Z, Fan Z, Tam VW, Bian Y, Li S, Illankoon ICS, Moon S (2018). Green building evaluation system implementation. Building and Environment 133:32-40.

[19] Zou Y (2019). Certifying green buildings in China: LEED vs. 3-star. Journal of Cleaner Production 208:880-888.

[20] Akcay EC, Arditi D (2017). Desired points at minimum cost in the optimize energy performance credit of LEED certification. Journal of Civil Engineering and Management 23(6):796-805.

[21] Komurlu R, Arditi D, Gurgun AP (2014). Applicability of LEED's energy and atmosphere category in three developing countries. Energy and Buildings 84:690-697.

[22] USGBC L (2020). USGBC LEED Projects, Washington, DC: US Green Building Council (USGBC). Retrieved from: https://www.usgbc.org/projects Date of access: 24.02.2020.
[23] Stanley S (2019). Infographic: Top 10 countries and regions for LEED in 2018, usgbc.org, Retrieved from: https://www.usgbc.org/articles/infographic-2018top-10-countries-and-regions-leed Date of access: 24.02.2020.

[24] Tatari O, Kucukvar M (2011). Cost premium prediction of certified green buildings: A neural network approach. Building and Environment 46(5):1081-1086.

[25] USGBC L (2009). LEED 2009 for new construction and major renovations., Washington, DC: US Green Building Council (USGBC).

[26] Golbazi M, Aktas CB (2016). Analysis of credits earned by LEED healthcare certified facilities. Procedia Engineering 145:203-210.

[27] OECD (Organization for Economic Co-operation and Development). (2008). Working Group on Waste Prevention and Recycling. A Study on Methodologies Relevant to the OECD Approach on Sustainable Materials Management.

[28] Gurgun AP, Komurlu R, Arditi D (2015). Review of the LEED category in materials and resources for developing countries. Procedia Engineering 118:1145-1152.

[29] Nodoushan MAS, Montazeran H (2012). The book review genre: A structural move analysis. ERIC Clearinghouse.

[30] McCrum-Gardner E (2008). Which is the correct statistical test to use?. British Journal of Oral and Maxillofacial Surgery 46(1):38-41. 